\title{
Who is Telling the Truth about the Egyptian Uprising 2011? Al-Jazeera versus the Egyptian Television
}

\section{Mustafa Hashim Taha*}

American University of Sharjah, United Arab Emirates

\begin{abstract}
This paper examines Al-Jazeera television channel's coverage of the Egyptian popular uprising and investigates the alleged bias in reporting that led the Egyptian authorities to close down al-Jazeera's office in Cairo. The paper uses framing and qualitative content analysis to explore Al-Jazeera's headlines as well as sources of information and news, particularly the interviewees on Friday, Jan. 25, 2011 (Friday of Anger). It also examines the sites of demonstrations highlighted in the coverage, namely Maidan al-Tahrir (Liberation Square). To see the divergence in news coverage, the paper juxtaposes Al-Jazeera's coverage and the official Egyptian television's coverage of the protest. It concludes that al-Jazeera's sources were predominantly leading figures in the Muslim Brotherhood, Islamists, and political groups calling for Mubarak's downfall. Al-Jazeera's interviewees and headlines saw no merit in the reshuffling of the government and considered that as a ploy to gain time and perpetuate Mubarak's repressive rule. On the other hand, the official Egyptian television, unsurprisingly, underscored and deplored acts of vandalism (Baltajah in Arabic), praised young protestors' efforts to protect the Egyptian national museum, called for calm, and asked the people to protect Egypt's security. In a nutshell, al-Jazeera's reporting was anti-government, highlighting voices demanding the toppling of the government, and calling for Mubarak's departure.
\end{abstract}

Keywords: Egyptian uprising; Al-Jazeera; Muslim brotherhood; President Hosni Mubarak

\section{Introduction}

The Arab Spring brought pleasant surprises to millions of Arabs around the world. Some scholars thought Arab masses were in a political coma. Many political activists felt so powerless that they left their homelands and sought refuge in other countries. But ordinary people across the Middle East have never lost confidence in themselves; they proved to be patient, brave, and patriotic. Some analysts misread the symbolism of these popular uprisings. Some argue that the peoples revolted for bread and employment; others claimed the uprisings are foreign conspiracies. These popular uprisings symbolize the dreams of suppressed nations, and their unflagging quest to live in dignity and pride.

The Tunisians triggered popular uprisings in the Arab world by proving that despots are vulnerable, and can subdue determined peoples. But, don't forget the Sudanese people who did it twice; toppling two military dictatorships, Aboud in 1964, and Numeiri in 1985. How could millions of suppressed peoples in neighboring Egypt, Libya, and Yemen know about and identify with the Tunisian success story if it were not for the mass media? Although Arab governments controlled major global media, these governments could not entirely control international satellite televisions, mobile telephony, and the Internet. It's not a surprise that most Arab nations shunned government-controlled media, and sought political news in foreign media channels (e.g., BBC and VOA), before the advent of $\mathrm{Al}$ Jazeera.

During the Arab Spring uprisings, Al Jazeera channel was one of the few Arab television channels that stood by the side of the popular protest particularly in Egypt. The pan-Arab channel played a catalytic role as a change agent. It challenged dictators' official media outlets and exposed their wrong-doings. That was a bold, yet risky editorial decision. Fortunately, for Al Jazeera, the popular uprisings succeeded in regime change in Tunisia and Egypt. The author of this paper used media ethnography and qualitative content analysis to appraise $\mathrm{Al}$ Jazeera's coverage of the Egyptian uprising critically.

\section{Media Dependency Theory}

Ball-Rokeach and De Fleur's media system dependency theory provides a useful conceptual framework that integrates phenomenology infield media research. "An advantage of media system dependency theory is that we can use the same basic concepts that apply to the abstract macro relations between systems to examine the more concrete (and micro) relations between individuals and the mass media". According to the media dependency theory, "the degree of media contribution to individual's construction of subjective reality is a function of one's direct experiences with various phenomena and consequent dependence on the media for information about these phenomena".

The media dependency theory suggested that media portrayals immensely affect individuals' perceptions of social conflicts if these conflicts are remote and far from individuals' lived experiences. Conversely, the closer social conflicts to the individual daily experience are, the less his/her perceptions will be congruent with media construction of reality. Thus, the perceptions of individuals who do not have direct experience with these conflicts can be described as media dependent.

According to Cohen et al. "there was a weak trend, indicating that the more remote the conflicts are from people's unmediated experiences - the more they are dependent upon the media for their knowledge, understanding, and interpretation of social conflicts". Their study of foreign news coverage in US media suggests the presence of

${ }^{*}$ Corresponding author: Mustafa Hashim Taha, American University of Sharjah, United Arab Emirates, Tel: +971 6515 5555; E-mail: mtaha@aus.edu

Received January 17, 2018; Accepted March 16, 2018; Published March 20 2018

Citation: Taha MH (2018) Who is Telling the Truth about the Egyptian Uprising 2011? Al-Jazeera versus the Egyptian Television. J Mass Communicat Journalism 8: 364. doi: 10.4172/2165-7912.1000364

Copyright: (c) 2018 Taha MH. This is an open-access article distributed under the terms of the Creative Commons Attribution License, which permits unrestricted use, distribution, and reproduction in any medium, provided the original author and source are credited. 
a "phenomenon that may be termed the severity syndrome of foreign conflict news". Cohen et al. argued that international conflicts are portrayed in the US media as "severe," "complex" and "unsolvable." Moreover, conflicts in African, Arab and Muslim countries are portrayed as crises situations. Journalists, wittingly or unwittingly, sustain negative coverage of international events not only because of their national biases, but also because of their heavy reliance on government sources.

\section{The Framing Theory}

Frame analysis becomes a powerful tool for investigating media effects on foreign policy formulation and implementation. Goffman conceptualized the notion of framing as a person's definition of a situation, or a context in which human interaction takes place. He referred to frames as "the schemata of interpretation that enable individuals to locate, perceive, identify and label events within their life space or the world at large". For Tuchman, however, a news frame represented a "window on the world".

According to Kuypers frames are "located in the communicator, the text, the receiver, and the culture at large". Frames "provide the interpretive cues for otherwise neutral facts." Driven by their interests and biases, news media construct stories in ways inducing audiences to draw certain conclusions.

Although framing is intentional or unintentional, the news media frame stories to advance their perspective, that of the target audience, or the views of the people involved in the event or issue. A "frame is a central organizing idea for making sense of relevant events and suggesting what is at issue" [1]. Gamson [1] refers to several framing devices, including metaphors, catchphrases, depictions, and visual images. Paletz and Entman [2] argued that the form of television news "disguises the process of selecting, framing, structuring, contextualizing, and linking stories; it conceals the reconstitution and reconstruction of reality". Thus, "Media discourse is part of the process by which individuals construct meaning, and public opinion is part of the process by which journalists ... develop and crystallize meaning in public discourse".

Political communication scholars have used frame analysis mostly to examine how journalists relied on story lines to depict political events, highlight issues, and describe political figures. They differentiated between news media frames and individuals' frames $[3,4]$.

Iyengar and Simon argued, "Print and broadcast news coverage of world events involving the use of US military force have propagated the world view and policy preferences of the incumbent administrations". Such news stories furnish their audiences with "contextual cues or frames in which to evaluate those subjects". Gamson and Modigliani [5] suggested that frames are formed by the interplay of journalistic routines and the influence of interest groups. Frames may reflect, however, ideological values of a particular social class and can be "driven by ideology and prejudice" [6].

Journalists use media frames to influence audiences' interpretations of media messages. Gitlin [7] defined media frames as "persistent patterns of cognition, interpretation, of selection, emphasis, and exclusion, by which symbol - handlers routinely organize discourse, whether verbal or visual". Entman [6] extended this notion and contends that media frames rely on salience, repetition, and association with familiar symbols while directing "attention away from other aspects". Thus, "the essence of framing is sizing - magnifying or shrinking elements of the depicted reality to make them more or less salient"
[3]. Entman [6] argues that frame diagnoses causes, make moral judgments, and suggest remedies. Thus, frames serve to "introduce or raise the salience or apparent importance of certain ideas, activating schemas that encourage target audiences to think, feel, and decide in a particular way".

But media frames may not resonate with individuals' frames. Audiences may accept, reject, or reframe these media frames $[8,9]$. Some studies examined the divergence between news media frames and public frames and depicted the public as an active rather than a passive audience. Since divergent frames compete for audiences' attention, some scholars consider framing as a competitive process.

\section{Literature Review}

Created by the Emir of Qatar in 1996, Al Jazeera emerged as the most important television channel in the Arab world. Entrapped by their national government-controlled television channels, Arab audiences were vying a new voice that resonates with their needs and concerns.

The Egyptian government created more than 25 state-owned channels to persuade the Egyptian people with the government's stories, and to counteract Al Jazeera influence. Nonetheless, both endeavors failed abysmally. Disillusioned Arab people found in $\mathrm{Al}$ Jazeera news what they were looking for; a reasonable degree of editorial independence, and voice that expresses their dissatisfaction with the political stagnation, corruption, and repression in the Arab world. According to Zayani and Sahraoui [10] Arabs identified with $\mathrm{Al}$ Jazeera, it is "the channel of Arab disenchantment, articulating what people want to say but cannot say with a rare sense of audacity".

AJA journalistic independence should be understood in context; the channel can't work against the wish of its benefactor, Qatar. One example is the dramatic change in AJA's coverage of Saudi Arabia. Following a Qatari-Saudi rapprochement, AJA's aggressive approach to Saudi affairs changed into a meek and complacent coverage. And although Qatar argues that Al-Jazeera operates autonomously and that Qatar would not interfere in the channels editorial policies [11], there were incidents where Qatar intervened to reign in $\mathrm{Al}$ Jazeera.

Arab audiences' identification with AJA is not coincidental, because the channel played the victim's role for its coverage of Afghanistan and Iraq. AJA's office in Kabul was attacked, probably in retaliation for the scoop, it got from its exclusive coverage of the war in Afghanistan. Moreover, AJA's office in Baghdad was attacked by a US warplane that killed one of its correspondents (Tariq Ayoub). A cameraman, Sami al-Haj, working for AJA was arrested in Afghanistan and sent to Guantanamo detention center because he was allegedly helping al-Qaeda. He was release after nine years of imprisonment for lack of sufficient evidence. Recently, there were reports that the Bush administration entertained the idea of bombing AJA headquarters in Doha. The US pressures on Qatar to reign in AJA sustained doubts about the U.S. ingenuity about promoting free speech.

AJA was instrumental in exposing the U.S. fallacies about the WMD in Iraq, as well as the atrocities committed by the U.S. officers against Iraqi detainees in Abu Ghraib prison. AJA also criticized some Arab states, including Egypt, for collaborating with the United States and ignoring the interests of their peoples. Because of its provocative reporting on Arab politics, Al Jazeera had been banned by many Arab governments - Saudi Arabia, Kuwait, Yemen - to name a few [11]. AJA office in Cairo was closed a few days after the beginning of the popular uprising. 
Saghieh claimed that "Aljazeera's Impact Derives From its ability to fuse two dimensions of globalization: sophisticated technology ("capitalist globalization") and an appeal to ethnic and religious populism (what might be called, from old Marxist phraseology, ("lumpenproletariat globalization").

Al Jazeera drew caustic criticism from many expected and unexpected sources. For example, former US secretary of Defense Donald Rumsfeld described the channel as a "mouthpiece of alQaeda," calling Al Jazeera "vicious, inaccurate and inexcusable". Pollock argued that AJA compromised its journalistic integrity to serve Qatar's political interests (Washingtoninstitute.org). But, some scholars tried to exonerate AJA and justify its biased reporting of some events. Iskandar and El-Nawawi [12] reasoned that AJA practiced "contextual objectivity" to meet its "audience's expectations". But, the concept of "conceptual objectivity" may not stand the scrutiny if coverage focuses on an in-group rivalry occurring in one contextual setting.

Al Jazeera coverage of the Arab uprisings bolsters the channel's standing in many countries. Some elites in some countries resented seeing $\mathrm{Al}$ Jazeera used for political expediency. Al Jazeera, to its credit, was persistently supportive of Arab civic societies. The channel endured some renowned employee defections probably because of its coverage of the uprising in Syria (e.g., Ghassan Ben Jeddo, and Luna AlShibl).

El-Nawawy and Iskandar [13] acknowledged bias in Al Jazeera coverage of the Iraq war, but justified it "contextual objectivity." The authors vindicated $\mathrm{Al}$ Jazeera reasoning that most media organizations frame news in a biased fashion [14]. And although Al Jazeera has more editorial independence compared to similar news channels (Al Arabiya and $\mathrm{Al}$ Hurrah for example), its sensational coverage of political news in Iraq and Afghanistan is well-documented.

Wojcieszak argues, "Western critics have described Aljazeera as an 'inexcusably biased' 'mouthpiece of Osama bin Laden', criticized it for covering uncontextualized violence, death, and torture, accused the channel of hampering the democratization efforts in Iraq, and blamed it for the rise of insurgence and the increase in kidnapping incidents." According to Samuel-Azran, "Aljazeera reports were "contaminated" and can be categorized as "propaganda,". But, this is not a negative characterization for $\mathrm{Al}$ Jazeera as it brands itself as "a counter-hegemonic force in the Middle East, a force that facilitates sociopolitical changes by criticizing and challenging the institutionalized structures and the prevalent social discourse in the Arab world". Zayani and Sahraoui [10] highlighted $\mathrm{Al}$ Jazeera's regionally remarkable editorial independence, and its sympathetic coverage of the sufferings of Iraqis and Palestinians with "a distinctly Arab perspective".

\section{Research questions}

RQ1: How did Aljazeera cover the uprisings in Egypt?

RQ2: Did Aljazeera's coverage adhere to the principles of journalistic objectivity?

\section{Methodology}

In this exploratory study, the researcher watched AJA channel news during the two weeks of the Egyptian uprisings. He watched the AJA news three times per day (morning, midday, and evening). The researcher also watched the news all day during the "Friday of Rage." He also watched the Egyptian television channel to see the difference in the coverage. On Saturday, Jan. 29, 2011 the researcher watched AJA as well as the Egyptian television concurrently from 4 p.m. to 10 p.m. to explore the variation in their messages. The researcher videotaped the headline news, and took notes of the key points. He also used Al Jazeera. net as an aid to search for more information on the AJA coverage.

The researcher gathered the data and transcribed it. He systematically classified the data into categories along thematic lines. He also took note of the influential interviewees on AJA and their statements. Then, he compared the coverage of the AJA and the Egyptian television to see the similarities and the differences in terms of language used as well as visuals.

To answer research questions, the researcher used media ethnography and qualitative context analysis. Madianou (2005), argues, "Media ethnography is gaining around as a legitimate research method." The researcher used personnel observation to observe and evaluate the coverage of both channels to ensure the information and the way they are broadcasted.

\section{Findings}

Major themes on AJA: An overriding theme of AJA coverage was demanding Mubarak's departure. AJA espoused the protesters' demands calling for preventing of hereditary by dissolving the Consultative Council and the Parliament, enacting constitutional amendments (namely articles 76 and 77) to facilitate free and fair presidential and parliamentary elections, and lifting the state of emergency.

Most of the AJA coverage was from the Tahrir Square (Maidan alTahrir). Demonstrations in other cities were also covered including Alexandria, Al Arish, and Suez City. The focus was on the martyrs and those injured by the security forces. Many of the television coverage highlighted the masses on the streets, and the popular shouts "the people want toppling the regime."

Another major theme was that the thugs (Baltajia in Arabic) were attacking the demonstrators. AJA suggested that some of these thugs were secret police in plain clothes. They are also supported by the national ruling party and some business people.

AJA's coverage also hailed the Egyptian army as a neutral and reliable bastion of democracy. The army was depicted as a defender of free speech, protecting the protestors from police brutality.

AJA also highlighted Mubarak speech, framing it as too little too late. Most of the guests who commented on the speech condemned it arguing that it did not respond to the needs of the people.

Prominent opinion leaders on AJA: AJA broadcast Sheikh Yusuf $\mathrm{Al}$ Qaradawi's statement asking the people to rise against the Egyptian government and calling on Mubarak to step-down. The respected Islamic preacher and his views on the uprising were featured numerous times. AJA also allowed Mohammed Hassanein Haikal, a prominent journalist known for anti-government stance, to use his program "Ma'a Haikal," to call on Mubarak to step-down and discuss issues of the Egyptian revolution. The pan-Arab channel also interviewed Mohammed ElBaradei, Amr Musa, Ayman Noor, Amr Khaled, some apolitical members of the "Youth of the Revolution," in addition to a number of the Muslim Brotherhood leaders including Isam Al-Irian and Abdel Munem Abu al-Fotooh.

\section{Major themes on Egyptian television - Egypt's News (Akhbar Masr)}

Most of the news on the Egyptian government-controlled television, Egypt's News, focused on "how to protect Egypt." The television highlighted complaints from numerous people who called-in from Nasr, Basateen, Roxy, and Rehab cities, complaining from looting and 
Citation: Taha MH (2018) Who is Telling the Truth about the Egyptian Uprising 2011? Al-Jazeera versus the Egyptian Television. J Mass Communicat Journalism 8: 364. doi: 10.4172/2165-7912.1000364

Page 4 of 4

mugging. The television also broadcast news from a looted and burnt down Carrefour store in Maadi City, in Cairo. The main theme was that the thugs (Baltajia) were terrorizing the people. The television also highlighted news that in Cairo as well as in Alexandria the youth were protecting their homes as well public properties, namely the Egyptian National Museum.

Another important message was the need to respect the law and reject chaos. Interestingly, the Egyptian television never broadcast from the Tahrir Square; but showed live images from quiet places in Cairo, including an angle of Six of October Bridge. The Egyptian television also demanded that the people respect the army's orders and abide by the curfew.

A major of the Egyptian television coverage was a conspiracy to destroy Egypt, and the people should pull together to protect it. For example, there were reports that the thugs (Baltajia) were attacking 57357 Hospital, which is a public hospital catering for children who suffer from cancer.

The Egyptian television also carried live all government news. It featured Mubarak witnessing the swearing in of the Ahmed Shafiq government. It also broadcast news refuting rumors about the fleeing of Jamal and Ala Mubarak to London.

Unlike AJA, the Egyptian television did not feature any prominent opinion leader, safe Sheikh al-Azhar. He called on the Egyptian people to safeguard Egypt and protect it.

\section{Discussion}

AJA's passionate coverage of the Egyptian uprising was not coincidental or episodic. The channel is known for criticizing Egyptian government and siding with its opponents. According to Seib, Aljazeera's coverage of Egypt 2005 infringed on government's rights. He added that "on the Election Day 2005 the Egyptian state channel didn't mention [anything] about the anti-Mubarak protests. However, Aljazeera aired an interview with Mohammed H. Haikal [whose known to be an anti-Mubarak icon, and he banned to talk with the national channel]. Moreover, in the parliament day election state Egyptian channel didn't report the violence accompanier the voting. Aljazeera; [however], ran footages with bloody faces and thugs waving machetes while police officers stood by".

If we compare the coverage of AJA and the Egyptian television of the Egyptian revolution we find that both of them were biased; AJA to the people and the Egyptian television to the government. But, if we compare AJA coverage of the Egyptian uprising with the BBC's, we find a striking difference. AJA did not give a room for the representatives of the Egyptian government or their supporters. On the other hand, the $\mathrm{BBC}$ interviewed Mohammed Albaradey, Ahmed F. Sorour, the head of the parliament, the new secretary of the National Party Majed Alsherbeny, Prime Minister Ahmed Shafiq, and the ex-vice president Omar Sulaiman. Thus, the BBC coverage is relatively more balanced compared to AJA's.

AJA's coverage of the Egyptian revolution sheds more light on the channel's political orientation. But, its potency should not be exaggerated. AJA provides Arab peoples with a voice [15], but its influence on the behavior of Arab states [16] should not be overstated.

\section{Conclusion}

This study shows that AJA coverage of the Egyptian uprising aimed at a regime change in Egypt. All the coverage including the news, the guests in the Doha studio, and the interviewees on the streets in Egypt were in favor of ousting Mubarak and dismantling his regime. AJA did not give room for the Egyptian government under Mubarak to voice its concerns. Thus, the coverage was squarely supportive of the Egyptian people against Mubarak's regime. Daring as it was, AJA's coverage of the Egyptian uprising could not have taken place if was not sanctioned by the Qatari authorities. It's inconceivable for any person, much less a satellite media channel, to speak openly against an existing Arab ruler without being questioned by local government authorities.

$\mathrm{Al}$ Jazeera's assertions about editorial independence did not stand scrutiny. The popular uprising during the Arab Spring, 2011, made it evident that the channel reporting of events is far from balanced. Al Jazeera was tough on Mubarak of Egypt, Gaddafi of Libya, and Saleh of Yemen. But, the channel was lenient and sheepish on Bashir of Sudan, Assad of Syria and the monarchy of Bahrain. Although controlled by the state of Qatar, $\mathrm{Al}$ Jazeera is increasingly becoming a media diplomacy tool for the Arab people.

\section{References}

1. Gamson W (1989) News as framing: Comments on Graber. American Behavioral Scientist 33: 157-166.

2. Paletz DL, Entman RM (1981) Media, power, politics. New York: The Free Press.

3. Entman R (1991) Framing U.S. coverage of international news: Contrasts in narratives of KAL and Iran Air incidents. Journal of Communication.

4. Pan Z, Kosicki GM (1993) Framing analysis: An approach to news discourse. Political Communication 10: 55-75.

5. Gamson WA, Modigliani A (1987) The changing culture of affirmative action Research in Political Sociology 3: 137-177.

6. Entman R (1993) Framing: Towards clarification of a fractured paradigm Journal of Communication 43: 51-58.

7. Gitlin T (1980) The whole world is watching: Mass media in the making and unmaking of the New Left. Berkeley: University of California Press.

8. Kosicki GM, McLeod JM (1990) Learning from the political news: Effects of media images and information processing strategies. Mass Communication and political information processing

9. Paterson C (1992) Television news from Frontline States. New York; Westport, Connecticut: Praeger.

10. Zayani M, Sahraoui S (2007) The Culture of Al Jazeera: Inside an Arab Media Giant.

11. El-Nawawy M, Iskander A (2002) Al-Jazeera: How the Free Arab News Network Scooped The World and Changed the Middle-East. London: Cambridge.

12. Iskander A, El-Nawawi M (2004) Al Jazeera and war coverage in Iraq: The media's quest for contextual objectivity. Reporting War Journalism in Wartime.

13. El-Nawawy M, Iskandar A (2003) Al-Jazeera: The Story of the network that is rattling governments and redefining modern journalism.

14. Aday S, Livingston S, Hebert M (2005) Embedding the Truth: A Cross-Cultura Analysis of Objectivity and Television Coverage of the Iraq War. The Harvard International Journal of Press.

15. Hafez Kai (2006) Arab Satellite Broadcasting: Democracy without Political Parties. Transnational Broadcasting Studies 15.

16. Lynch M (2006) Voices of the New Arab Public: Iraq, Al-Jazeera, and Middle East Politics Today. Columbia University Press. 